\title{
Envisioning Present and Future Land-Use Change under Varying Ecological Regimes and Their Influence on Landscape Stability
}

\author{
Marcela Prokopová ${ }^{1}$, Luca Salvati ${ }^{1,2, *}$, Gianluca Egidi ${ }^{3}$, Ondřej Cudlín ${ }^{1}$, Renata Včeláková ${ }^{1}$, \\ Radek Plch ${ }^{1}$ and Pavel Cudlín ${ }^{1}$ \\ 1 Global Change Research Institute, Czech Academy of Sciences, Lipová 9, \\ CZ-37005 České Budějovice, Czech Republic \\ 2 Council for Agricultural Research and Economics (CREA), Viale S. Margherita 80, I-52100 Arezzo, Italy \\ 3 Department of Agricultural and Forestry Sciences (DAFNE), Tuscia University, Via San Camillo de Lellis, \\ I-01100 Viterbo, Italy \\ * Correspondence: luca.salvati@crea.gov.it
}

Received: 30 July 2019; Accepted: 22 August 2019; Published: 27 August 2019

check for updates

\begin{abstract}
Climate change plays an important role in shaping ecological stability of landscape systems. Increasing weather fluctuations such as droughts threaten the ecological stability of natural and anthropogenic landscapes. Uncertainty exists regarding the validity of traditional landscape assessment schemes under climate change. This commentary debates the main factors that threaten ecological stability, discussing basic approaches to interpret landscape functioning. To address this pivotal issue, the intimate linkage between ecological stability and landscape diversity is explored, considering different approaches to landscape stability assessment. The impact of land-use changes on landscape stability is finally discussed. Assessment methodologies and indicators are reviewed and grouped into homogeneous classes based on a specific nomenclature of stability aspects which include landscape composition, fragmentation and connectivity, thermodynamic and functional issues, biodiversity, soil degradation, and ecological disturbance. By considering land-use change as one of the most important factors underlying climate change, individual components of landscape stability are finally delineated and commented upon. In this regard, specific trajectories of land-use change (including agricultural intensification, land abandonment, and urbanization) are investigated for their effects on ecological stability. A better understanding of land-use impacts on landscape stability is crucial for a better knowledge of processes leading to land degradation.
\end{abstract}

Keywords: disturbances; landscape structure; desertification; resilience; Europe

\section{Introduction}

Stability is a concept that involves many aspects and principles from both ecological and socioeconomic perspectives [1-3]. Mechanisms, features, characteristics, and functions make it difficult to assess states or predict future reactions of ecosystems to some drivers of global change, such as land-use change [4-6]. Drivers of changes in biodiversity, ecosystem functions/services, and human well-being are shown in Figure 1. Land-use change can be considered one of the most important drivers of landscape stability decline under global changes [7-9]. Specific models separately predicting climate change, land-use transformations, and population dynamics have been proposed in recent times [10-12]. However, models forecasting (landscape) ecological stability based on an integrated and prospective analysis of these three research domains have been relatively scarce and designed for specific local contexts [13-16]. In these regards, some key questions remain unclarified: (i) what are the 
implications of these trends (separate and joint) for ecological stability? And, more specifically, (ii) what are the possible thresholds in land-use transformations significantly affecting landscape stability?

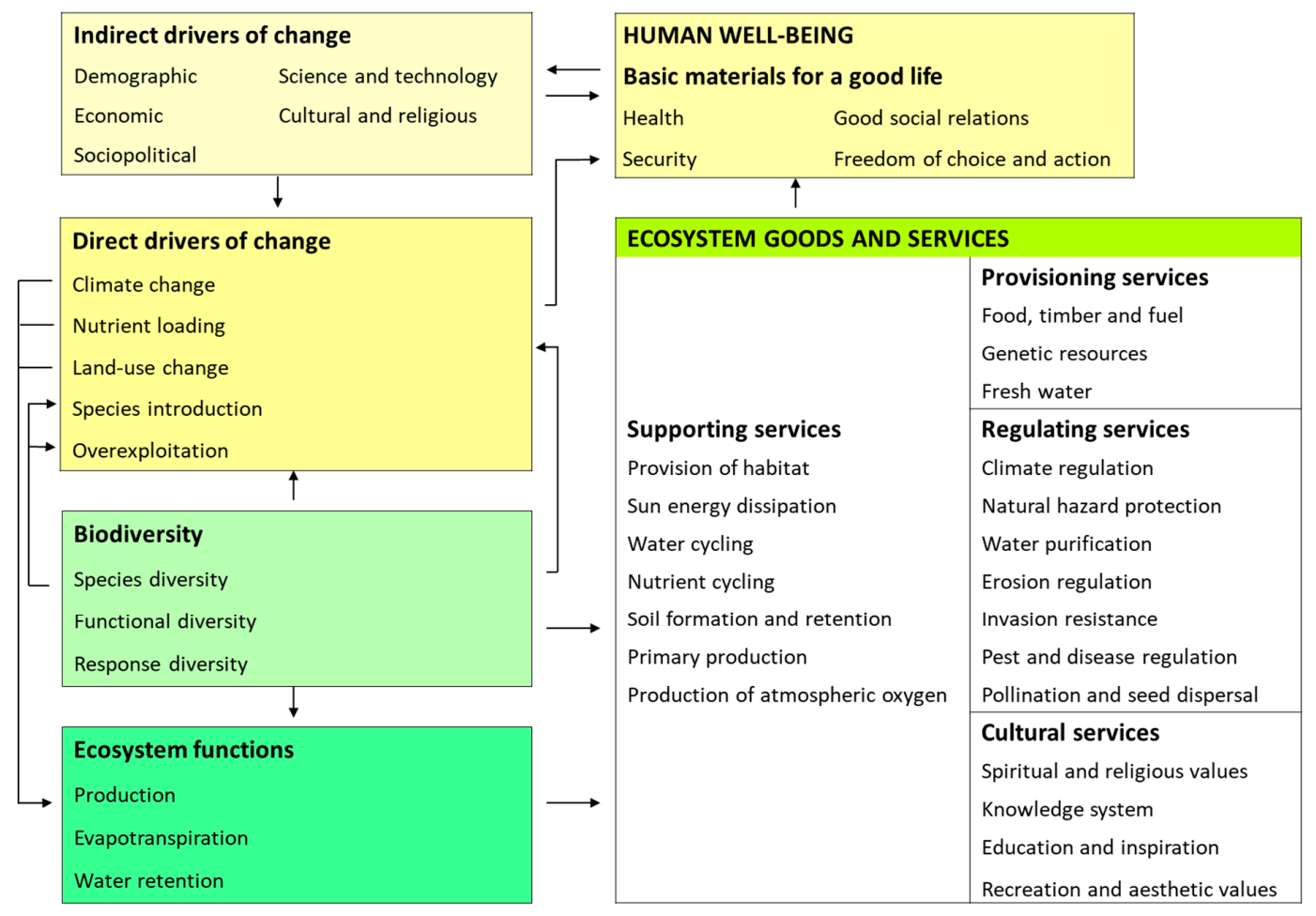

Figure 1. Drivers of changes in biodiversity, ecosystem services, and human well-being. Source: Secretariat of the Convention on Biological Diversity, Global Biodiversity Outlook 2, Montreal, 2006.

Since landscape stability has a very complex character and a multidisciplinary nature, ecological stability is intimately related to land-use transformations and it can be influenced by such changes at the same time [17-19]. This leads to multiple ways of how to perceive and quantify it, depending on of the variety of assessment techniques and particular problems it focuses on, e.g., depending on specific issues of any given landscape type [20-24]. Urbanization, crop intensification, and land abandonment are examples of processes of land-use transformation with a strong impact on landscape stability. It is most likely that each landscape type will need a different assessment of stability depending on which issues that threaten it are the most relevant for that given type [25-28]. Based on this premise, a reflection on the concept of ecological (landscape) stability concept is proposed in this paper, focusing on assessment methodologies in relation to global change processes that involve land-use transformations, climate variability, and demographic dynamics.

More specifically, the intimate linkage between ecological stability and landscape diversity is explored with an aim to address this pivotal issue, considering different approaches to landscape stability assessment, and the impact of land-use change on landscape stability is discussed. Assessment methodologies and indicators are reviewed and grouped into homogeneous classes based on a specific nomenclature of stability aspects that include landscape composition, fragmentation and connectivity, thermodynamic and functional issues, biodiversity, soil degradation, and ecological disturbance. By considering land-use change as one of the most important factors underlying climate change, individual components of landscape stability are finally delineated and commented upon. In this regard, specific trajectories of land-use change (including agricultural intensification, land abandonment, and urbanization) are investigated for their effects on ecological stability. The paper is composed of five main sections. Section 2 provides theoretical and operational definitions of 'ecological stability'. Section 3 investigates properties of landscape stability. Section 4 reviews conditions for landscape stability under land-use transformations. Section 5 describes indicators and metrics of 
landscape stability. Finally, Section 6 re-frames the latent relationship between land-use change and landscape stability with examples from a European country. A brief discussion section provides the necessary conclusion to this commentary.

\section{Defining 'Ecological Stability'}

'Ecological stability' has been defined as the ability of a given ecosystem to return to the initial equilibrium state after disturbance [29]. Additionally, this notion has been taken as an intrinsic ability to maintain ecological functions despite disturbance [30]. Ecosystem stability emerges from three complementary attributes [31]: resilience, adaptability, and transformability. While scholars have traditionally concentrated on resilience and adaptability, more recently—in a time of global change-it seems that the concept of transformability is becoming equally important in landscape ecology [32,33].

'Resilience' was defined as a measure of the ability to absorb change (e.g., disturbance) and eventually recover and reorganize [34] so that vital components of the system (plants and animals) will still retain the same organizational structure, functions (e.g., productivity), and interactions, feedbacks, and identity $[35,36]$. Resilience was later used to better understand general principles governing transformations of socio-ecological systems through cycles of change [37-39]. 'Adaptability' is the ability of a given system to adjust to changes, either internal (plant succession and management practices) or external (rainfall, temperature, climate change, and exchange rates) and thereby to follow a current predetermined succession trajectory within the current stability domain [40] and maintain a desirable system's state or functions [41]. 'Transformability' refers to processes altering the nature of a given system [31] and is defined as the intrinsic capacity to create a new stable landscape when existing ecological, economic, or social structures become untenable, i.e., untried beginnings from which a new way of living evolves [38].

Based on these premises, there has been a conceptual shift in the notion of 'ecological stability' over the last century. The original view implying natural balance and equilibrium paradigms, saying that biochemical cycles and energy flows generate self-organizing feedbacks contributing to ecosystem stability [22,42,43], was later questioned and alternatives emerged admitting loose-equilibrium conditions, non-equilibrium conditions, or multi-equilibrium models in which fluctuations are an essential part of the system. Further attention was given to hierarchical patch dynamics [44] where ordered structures emerge hierarchically and lower levels form building blocks for higher levels of organization, or to adaptive cycles (i.e., based on a concept implying adaptability of socioecological landscapes (SEL), adaptive cycles of social ecological system (SES), or complex adaptive systems (CAS) [31,45,46]). By introducing a 'panarchy' theory, these concepts were linked with the nested hierarchy of adaptive cycles arranged according to their characteristic scale, in which natural, human, and social-ecological systems are "interlinked in never-ending adaptive cycles of growth, accumulation, restructuring, and renewal" across scales [38].

\section{Properties and Conditions Contributing to Landscape Stability}

The term 'stability' has been used in the analysis of landscape sustainability or interacting socio-ecological systems in various disciplinary contexts and while giving room to different interpretations of complex issues $[29,30,38]$. Landscape stability is typically characterized by complex relationships and has many issues at stake [31]. Research has focused on single aspects of stability rather than acknowledging its multi-dimensional nature $[6,27,28]$ which leads to vastly different interpretations of this notion [32,33]. Examples of the ways in which landscape stability has been described in recent literature are illustrated in the following paragraphs.

\subsection{Unchanged Land Use}

Experts on historical land-use change analysis use the term 'landscape stability' in the sense of unchanged polygons of land use [47-49]; some of them have also used the term 'habitat stability' to refer to its continuity of unchanged existence [17]. Stability here expresses the lack of change in land 
use with no direct relation to ecosystem (functional) stability (even though some authors have tried to identify the linkage between land-use continuity and ecosystem biodiversity [50].

\subsection{Stable Species Composition}

'Landscape stability' is sometimes perceived as stability of species composition [51], but this stability is not a necessary pre-requisite for stability and resilience of ecosystem functions. For instance, in communities experiencing climate warming, cold-adapted species are expected to decline while warm-adapted species may increase, although similar sets of functions might be achieved by very different community structures. Turnover in species communities may be the key factor allowing for resilient functions [23].

\subsection{Biodiversity Conservation}

Early studies [52,53] in ecosystem networks like the European Ecological Network (EECONET) have addressed issues such as 'biodiversity conservation' with an intrinsic target of enabling migration and stability of populations and communities, especially in anthropogenic landscapes, focusing especially on connectivity and spatial arrangement of patches.

\subsection{Stability of Ecosystem Services}

'Stability of ecosystem services' [54,55], seemingly linked to the stable functioning of the ecosystem, may be conflicting in some cases, mainly because of the intrinsic trade-offs of ecosystem services (e.g., production services versus supporting/regulatory services). This notion has been frequently used in a context of socio-ecological systems and refers to landscape sustainability [45]. Targets are mainly functions and services characteristic of various levels of, for example, landscape organization or species composition, eventually altered by adaptation or transformation processes [46].

\subsection{Stable Soils}

Another way to interpret stability of landscape is related to stability of soils in relation to soil erosion [56] or soil degradation [12,57-59]. Soil is the foundation of nearly all land uses, and therefore soil quality stands as a key indicator of sustainable land use [60] and represents a basic condition for resilience of agro-ecosystems [61]. Many landscapes have lost stability due to processes of land degradation, leading to a reduction in ecological resilience [62-64].

\section{Stable Landscapes and Land-Use Change}

Stability is influenced by ecosystem (or landscape) characteristics which serve as preconditions for proper ecosystem functioning. Biodiversity, landscape metrics (connectivity versus fragmentation), characteristics of species and ecosystem functioning (feedbacks and modular structures) are relevant variables. Components of ecosystem stability act at several levels: individual species affect the community structure and can influence the structure of entire ecosystems, mediated by landscape level heterogeneity and/or habitat connectivity [23]. Ecosystem performances are also influenced by outer factors. We can look at such factors from two perspectives: (i) as a driver influencing directly (i.e., land cover change) or indirectly (i.e., climate change, pollution, and some types of land-use change) the ecological stability of landscapes, or (ii) as a pressure, i.e., factors that cause ecosystem disturbance and perturb its long-term stability. To protect and enhance landscape stability, measures that promote sustainable land-use changes should be implemented. Relevant processes and mechanisms that underpin the latent relationship between landscape stability and land-use changes are briefly discussed in the following paragraphs. 


\subsection{Multi-Level Diversity}

The mainstream ecological literature interprets resilience as related to some aspects of diversity, mainly through redundancies, response diversity, and spatiality at multiple observation scales [1;13;35]. Vegetation structural diversity and diversity in habitat response to exogenous disturbance have been recognized as basic mechanisms underpinning ecosystem services [14] and the contributing role of functional diversity to reassembly of ecological communities has been more recently emphasized $[65,66]$. By looking at the individual level, the effect of genetic diversity is key to promoting adaptability of wild species [67,68] and agricultural species [69], making them more resistant against diseases, pests, and nutrient deficiencies $[45,70]$.

Species diversity is related to higher redundancy, leading to different impacts and responses to environmental change or perturbation [71]. This variety is crucial for response diversity and determines resilience, adaptability, and flexibility of ecosystem functions [5;23;32]. This also holds for biodiversity in mixed agro-ecosystems, especially under conditions of global change [33,72], because it allows for the spreading of risks throughout the entire cropping rotation [16] and performs greater complementary and functional diversity [73] with higher resilience to fungal diseases and pests [74]. The notion that agriculture depends on biodiversity is key in the approach of resilient agricultural systems [75-77].

Considering diversity at the landscape level, spatial heterogeneity can stimulate a higher resistance of ecosystem functions to external shocks by providing a range of resources and refugees and therefore facilitating the persistence of individual species under environmental perturbations. It supports higher overall species richness [78], and, therefore, functional redundancy [23]. The fine-grained distribution of communities at different successional stages allows for patch dynamics to operate with dispersal of species between patches [13]. To balance and complement homogenizing trends, diversity should be promoted for all landscape dimensions [32]. Adaptation of agriculture to climate change can be enhanced by encouraging flexibility in land use, crop production, and farming systems. It is necessary to consider the multifunctional role of agriculture [79] because a large number of components is a prerequisite for preservation of complex adaptive systems [67].

\subsection{Species Composition and Community-Level Mechanisms}

Not only the number of species but also the specific composition and structure of biological communities is of great importance for landscape resilience. Desirable characteristics of species assuring high resilience and adaptability to external shocks include low sensitivity to environmental change, high rate of population growth, phenotypic plasticity, and allele effects caused by population concentration or dispersion [23]. Mechanisms operating at the community level include low correlation between response and effect traits for higher resistance [80] and low sensitivity of species highly connected in interaction networks as an insurance against extinction cascades [5].

\subsection{Landscape Composition, Landscape Level Characteristics, and Mechanisms}

Apart from landscape diversity listed above, natural habitat content, patch connectivity, the ability to respond behaviorally or genetically to environmental changes [67], and the potential for alternative stable states [40] are important variables. Natural (or semi-natural) habitats tend to provide a greater range and amount of resources, which promotes higher species richness and larger population sizes $[81,82]$. This reflects greater genetic diversity and functional redundancy, both of which promote the resistance of ecosystem functions to external shocks [69].

Micro-scale landscape structures reflected in spatial arrangements, shape, size, quality, and connectivity of patches, lines, and small interactive elements play an important role in ecosystem dynamics and are the principal factor of landscape stability [52]. Configuration of patches influences the migration capabilities of organisms. In this regard, landscape connectivity is one of the main mechanisms which underpins the maintenance of ecosystem services and the reassembly of ecological 
communities under increasing climate change and variability [14]. Meta-population theory suggests that populations in well-connected landscapes will persist better or recolonize more rapidly following environmental perturbation, a phenomenon known as the 'rescue effect' [23]. The concept of 'Territorial Systems of Ecological Stability' [51] has been proposed to apply to a cultural landscape in order to create conditions for the permanent existence of species and communities in the natural gene pool of the landscape that will also interact with un-natural and semi-natural surrounding landscapes. It is composed of systems of bio-centers and biotic migration corridors hierarchically arranged within bio-geographical units.

Among landscape-level mechanisms supporting higher ecological stability we can list modular structures that help hedge against risk of resilience depletion caused by over-connectedness in system organization and functions [32], and tight feedbacks maximizing the energy capture and reinforcing the system structure and processes enhancing stability at the same time [21,22]. Such knowledge contributes to an improved detection of ecological thresholds [32], transformability in the sense of a 'capacity to create a new stable landscape' [38], and flexibility via multi-functional agriculture [79].

\section{Assessment of Landscape Stability: Indicators and Metrics}

Most stability metrics are affected by land-use change. Conversely, a decrease in ecological stability may cause changes in land use and land cover as a reaction to ongoing degradation and, in the case of agricultural or forestry use, transformations followed by a consequent decrease in profitability of the original land use. For this reason, it is necessary to distinguish the use of indicators to (i) identify pre-requisite conditions for ecosystem stability and (ii) detect changing variables and characteristic processes, indicating that stability is already low or is decreasing further because it causes a decrease in the prerequisite characteristics (i.e., species diversity) or because of the action of some outer drivers (i.e., population growth) causing such changes. There are many interconnected aspects of landscape and ecosystem stability and, hence, several assessment methodologies have been proposed using different indicators [83]. Following the particular aspects of landscape or ecosystem stability, we can divide these into several groups with specific indicators, as seen in Figure 2. In the following sub-sections, eight dimensions were specifically addressed: landscape composition, landscape configuration, thermodynamic properties, ecological functions, biodiversity, soil degradation, ecological disturbance, and landscape dynamics.
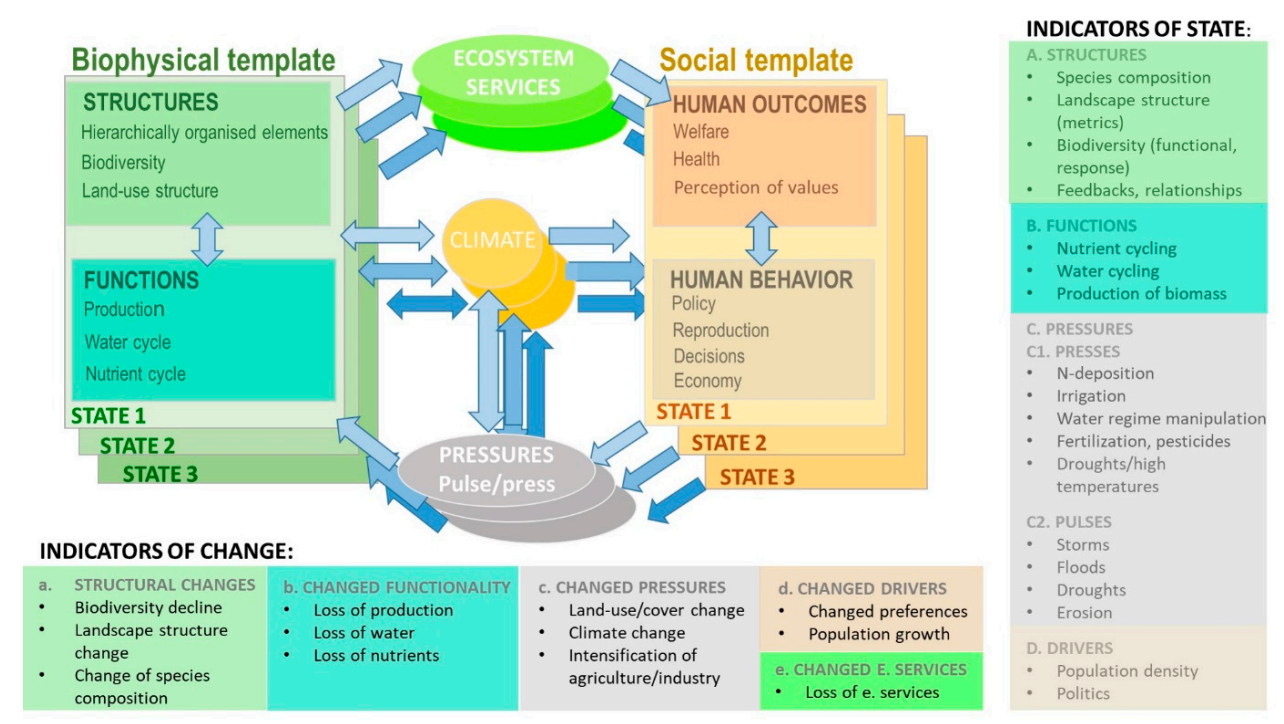

Figure 2. Apparent and latent relationships between factors that influence ecological stability and related indicators assessing state and change [84] (E. means 'Ecosystem'). 


\subsection{Landscape Composition}

Natural areas contain a high amount of resources, species richness, population sizes, redundancy, genetic diversity, response diversity, and resistance of ecosystem functions $[69,81]$. In agricultural landscapes, natural and close-to-natural elements are essential to support functional agro-biodiversity [85-87]. For instance, such methodology has been effectively applied in research assessing the ecological stability of landscape portions, based on a classification of land use according to proximity to natural conditions or states based on pristine vegetation characteristics and long-term continuity in land use and management. Landscapes with a low ecological stability are functionally compared with landscapes at high ecological stability [88].

\subsection{Landscape Configuration}

This widely used approach is based on the assumption that landscape stability increases with environmental heterogeneity and the interconnection of natural (or close-to-natural) habitats. These features are described by landscape composition (relative proportions of patch types in the landscape) and landscape configuration (spatial pattern of patches in the landscape). This landscape microstructure, reflecting specific spatial arrangements, shape, size, quality, and connectivity of patches, lines, and small interactive elements, plays a basic role in landscape dynamics and is the main factor influencing landscape stability [52].

Basic indicators for assessment of this specific issue include landscape composition (total class area and proportion of land use types), number of patches, patch dimensions (e.g., mean patch area [89]), patch density, mean shape index [90], mean proximity index, degree of isolation [47], fragmentation, land cover diversity and connectivity [25], aggregation indexes and weighted mean patch fractal dimension [48], and alternative metrics of "landscape openness" [90]. A contagion index has been proposed which involves measuring the extent to which landscape elements are aggregated [20]. Similar methodologies of landscape assessment have been adopted to evaluate multi-functional ecosystems according to basic ecological characteristics using spatially explicit models [90].

\subsection{Thermodynamic Properties}

Ecosystems self-organize towards maximum energetic, hydric, and material-related efficiency [91] through complexification of energy and matter-transferring pathways and the establishment of cyclical processes [92]. These self-organizing processes produce gradients (the so-called 'energy hierarchy', [93]) when receiving a through-flow of exergy [94]. Exergy capture (uptake of utilizable energy) is rising and its storage is rising on both bases (materialistic and structural). With this increasing structural diversity, the diversity of flows and the system's ascendancy also rises, which is considered a measure of ecosystem organization complexity [95]. This measure is related to system stability, resistance, and the ability to compensate for disturbing effects of the environment because it increases functional diversity, helping systems to recover after perturbation [96]. Resilient and sustainable landscapes are characterized by minimal direct energy or energy-demanding resource inputs and maximal internal cycling [97]. The inherent capability of ecosystems to self-order and self-regulate makes them also less dependent on external conditions, buffering against variability in resources and climate [98]. Anthropogenic degradation outlines a shift from an evolved state of self-ordering complexity toward conditions with more simple structures and functions that are less efficient [99].

The most commonly used indicators include 'emergy'. Such metrics have been adopted to identify areas characterized by distinctive spatial hierarchies [22], biomass and its fractions, soil organic matter, storage of nutrients in the soil, and resident time of imported exergy [100]. Exergy is an appropriate holistic indicator assessing the environmental health of ecosystems [101,102]. Other indicators are frequently used, including transformity, which is a ratio calculated by dividing emergy input by available energy output. This metric indicates the relative hierarchical position of each energy flow in the ecosystem [93], a normalized spectral entropy able to describe the degree of regularity (orderliness) 
within an ecological time-series based on its power spectrum [103] or ascendency, as proposed by [96]. In this regard, the authors of [46] have introduced a spatio-temporal analysis of a normalized difference vegetation index (NDVI) time-series.

\subsection{Ecological Functions}

In agricultural land, resilience can be distinguished on the basis of critical functions such as primary biomass production, regulation of hydrological processes, and surface energy balance [12]. Regulation of hydrological processes can be assessed by estimation of water runoff [104]. Water retention and recycling are fundamental ecological processes and the water retention index is a reliable measure of the water cycle. Wetlands promote the hydrological resilience of downstream flow to extreme conditions [15] and some scholars have adopted wetland areas [4] or a number of geographically isolated wetlands as a proxy for water retention capability of a given landscape. Works [105-107] have proposed a parametrization of land cover data using landscape water potential indicators. Retention of nutrients can be partly assessed by biomass and productivity, but the loss of basic ions can be measured at the end of river basin as water conductivity by implementing a specific energy-transport-reaction model [91]. Another group of indicators widely used in ecological applications is related to surface energy balance, mostly related to climatic functions, and includes potential evapotranspiration as one of the most relevant metrics [108]. A modified vegetation quality index based on the environmentally sensitive areas index (ESAI) framework has also been proposed by defining surface energy balance according to three topical dimensions (soil erosion protection, drought resistance, and vegetation cover).

\subsection{Biodiversity}

Thermodynamic principles have many consequences, including higher species richness and heterogeneity [105]. Driven by evolution, biodiversity continuously generates new energy-dissipative structures to delay collapse and entropy $[94,101]$. Alteration in species composition and ecosystem structure is fundamental to survival, contributing to thermodynamic equilibrium [92]. Entropy-based indices like Shannon's H diversity and Pielou's J evenness of species composition and landscape (or habitat) use [109-111], together with biodiversity estimates from remotely sensed images [112], could serve as proper indicators of system complexity and self-organizing development, leading to higher ecological stability.

\subsection{Soil Degradation}

Landscape resilience and stability are affected by the soil system which is in turn affected by the inherent balance between inputs and losses of nutrients and carbon [62]. Indicators assessing resilience of production functions include soil health variables such as total and mineralizable $\mathrm{N}$ and total C [113], soil organic matter [114], mineral P and K [115], pH and cation exchange capacity [116], soil physical properties [117], texture [118], structural stability [119], and soil-water relations. Work [120] has proposed a system evaluating sensitivity of land to degradation (ESAI) that combines soil properties with other factors (climatic, vegetation, and social]). This approach has been further developed for evaluation of ecological resilience by composing three indices investigating quality of soils, climate, and water [121]. Finally, other indicators such as pest pressure [122], weed pressure [87], frequency of landslides [10], and severity of soil erosion [123] have also been proposed as reliable indicators contributing to a better knowledge of agro-ecosystem resilience mechanisms.

\subsection{Ecological Disturbance}

Approaches focusing on disturbance combine two key variables representing time and space to describe potential disturbance dynamics. The temporal variable $(\mathrm{T})$ is the ratio of the disturbance interval (i.e., the time between successive disturbance events) to the time required for a disturbed site to recover to a mature stage. The spatial variable (S) is the ratio of the size of the disturbance to the size of 
the landscape. The mechanisms behind disturbances also determine the components of resilience and the inherent characteristics of ecological processes. Great precision is thus required when answering the question 'Resilience of what, to what?' [37]. For instance, in the case of agro-ecosystems, disturbance patterns can be chronic (e.g., soil degradation and toxicity), acute (e.g., heat waves and pest invasion), high intensity (e.g., extreme weather), or low intensity (e.g., tillage). Defining disturbance regimes and evaluating potential long-term, gradual changes when monitoring and measuring resilience are particularly relevant issues in ecological studies [124].

\subsection{Landscape Dynamics}

Widely used indicators of landscape dynamics assess land-use change based on diachronic information based on maps of historical and actual landscapes. Three basic interpretations of these changes have been elaborated upon, as shown in Figure 3.

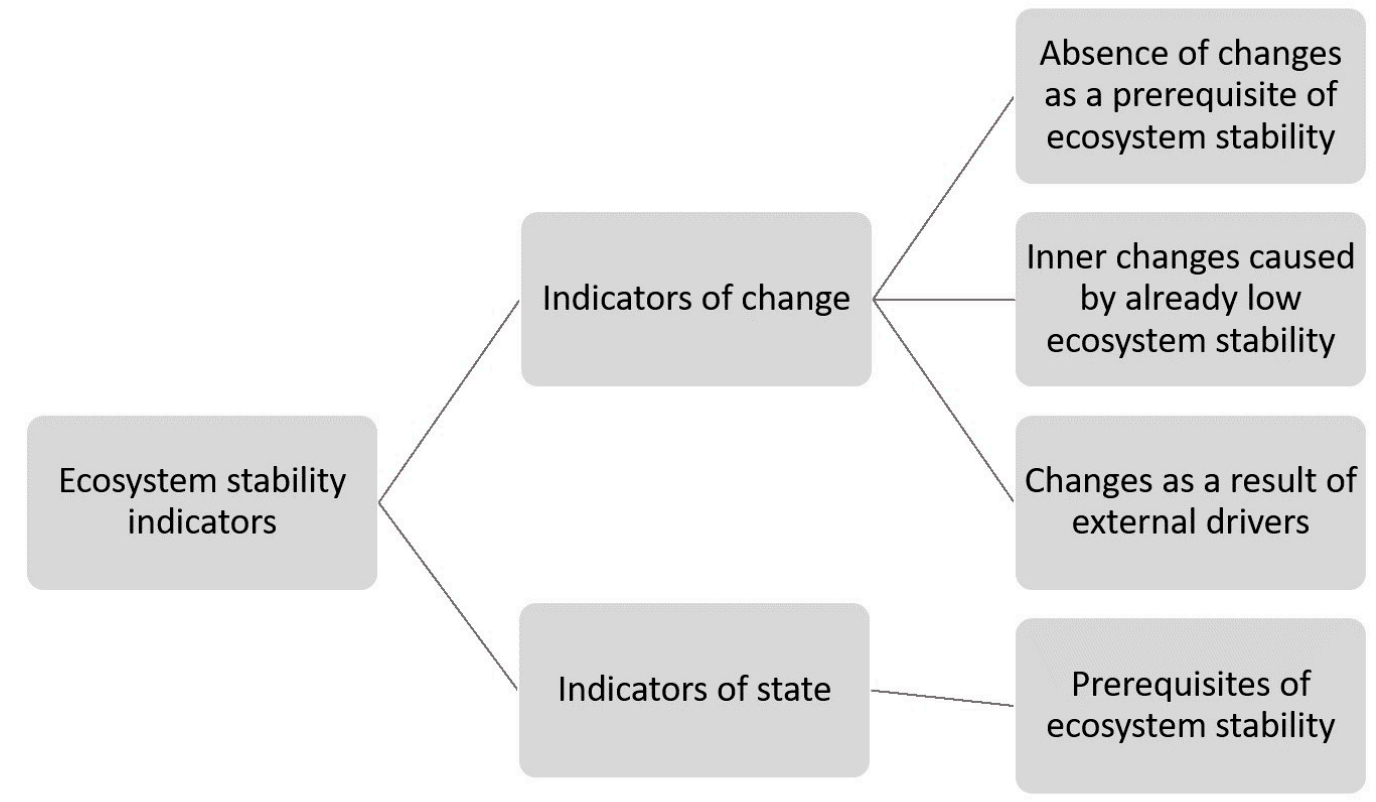

Figure 3. Stability indicators classified according to different interpretations of land-use change.

First, landscape dynamics are based on the assumption that long-term habitat continuity ensures higher ecological integrity and provides enough time to adjust to changing conditions, to develop structures and processes, and therefore to maximize the use of energy. In other words, land-use stability determines ecosystem stability (however, climate change can alter this principle). Unchanged polygons (ensuring continuity of ecosystems) indicate a prerequisite for stability. Changed polygons indicate a break point in stability maintenance and development. In this regard, habitat continuity contributes to maintaining high landscape quality $[125,126]$. Strategies of biodiversity conservation have been based on measures promoting habitat continuity in the case of, for example, semi-natural grasslands [49]. The importance of forest continuity for preserving landscape functional performances has also been demonstrated [106]. To assess continuity, landscape trajectories (alternatively labelled as 'land-use-history profiles') or land-cover transitions have been recently used because they can detect not only the existence of changes but also the speed and direction of processes, showing, for example, trends and drivers of land degradation [127]. They are usually described as sequences of some landscape types classified into homogeneous clusters by magnitude and direction of change, using expert valuation of naturalness (e.g., deviation from potential natural vegetation [47]).

Second, stable segments of land use may also reflect the small effect of outer drivers (such as population growth) that cause land-use changes, indicating the degree of human pressure. Unchanged landscape polygons reflect stable social-ecological systems with a more stable socioeconomic condition 
and less strong drivers of change. Changed polygons indicate the pressure of outer drivers, namely, population growth, agricultural intensification, or even land abandonment. Again, analysis of landscape trajectories adopts a more qualitative representation of spatial data, whereas areas with the same land cover class can be thematically separated following different land-use classes and land cover history $[128,129]$. This approach provides us with a tool which allows a refined interpretation of ongoing landscape changes and their ultimate drivers [109].

Third, land-use changes have also been seen as a result of low stability leading to progressive shifts in ecosystems towards alternative states and therefore detectable landscape changes. We should interpret land-use and land cover changes properly in order to take appropriate land management measures. In this interpretation, human decisions to modify land use are a consequence of changes that have already happened as a result of low stability conditions (Figure 4). In other words, ecosystem instability causes instability of social systems that determines further ecosystem instability. No changes indicate functional stability, while changes are the result of inner processes caused by low stability (low stability is itself a driver for further stability decrease and can lead to land-use changes).

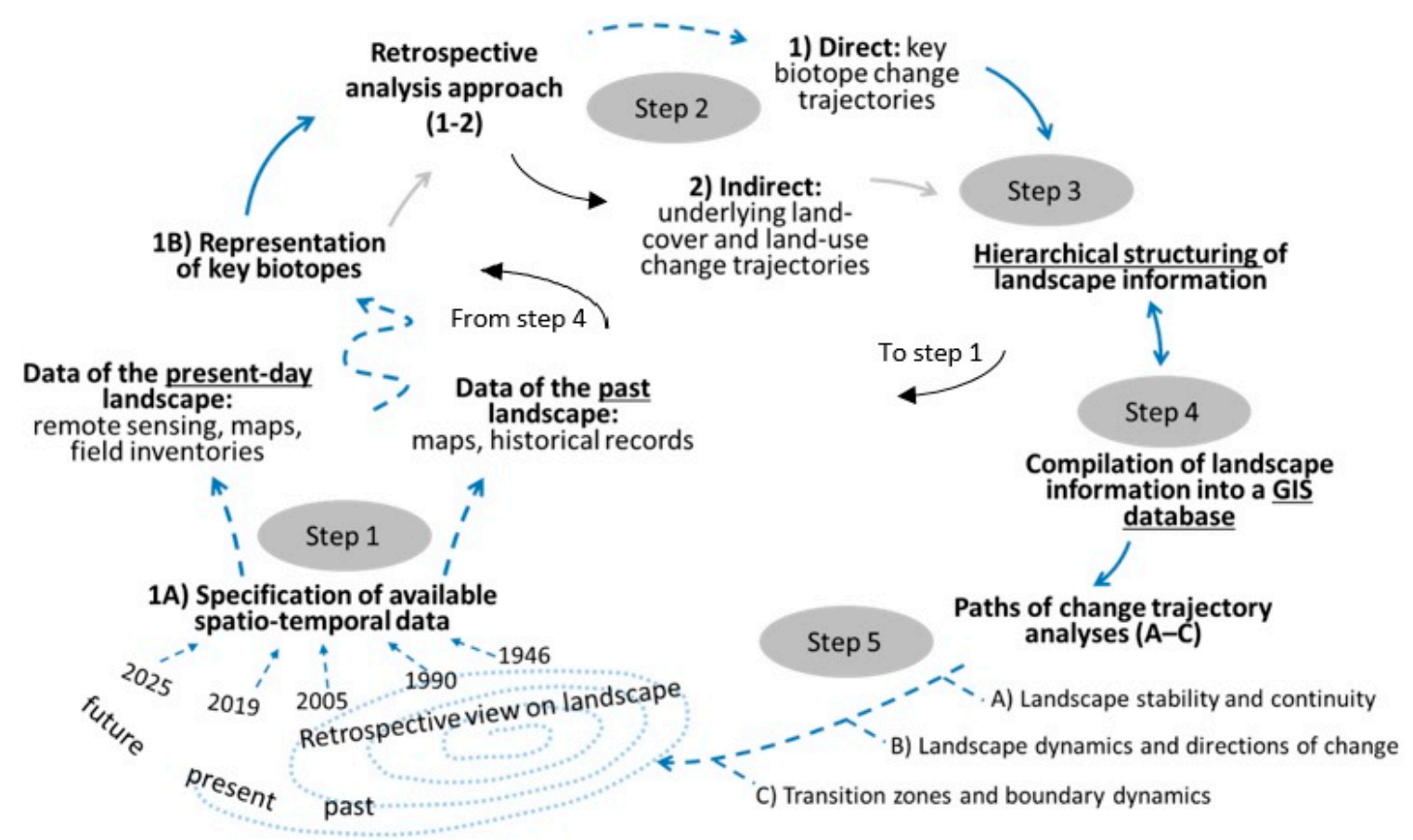

Figure 4. A conceptual model for (direct/indirect) retrospective analysis of landscape change trajectories including methodological solutions during sequential work steps, adapted from [49].

\section{Re-Framing Land-Use Change and Landscape Stability in Europe with Examples from Czechia}

In Europe, basic trends in land-use changes have been identified in past decades, including intensification of agriculture in lowlands and abandonment of agricultural land in more marginal, remote districts $[2,27,60]$. Additionally, urbanization has exerted an increasing impact on the stability of socioeconomic systems. Impacts on ecosystem stability and socioeconomic consequences of such land use changes are discussed in the following sub-sections.

\subsection{Intensification of Agriculture}

Today's agriculture generally aims to produce large quantities of food against the lowest economic costs [130]. These short-term goals lead to conflict with conservation and management of biodiversity and other long-term ecosystem services [131]. Increasing dependence on a small number of agricultural commodities [132], unsustainable mining of water and soil resources [133], and the biological simplification of agricultural systems [77] are potential sources of instability and vulnerability to climate 
change and unpredictability, endangering critical ecosystem services to and from agriculture [124]. Moreover, a short-term focus on maximizing productivity can endanger ecosystem services in such a way that dependence on external inputs such as fertilizers and pesticides increases in order to maintain productivity [61]. Lowland areas in Europe have seen a drastic increase in intensive agriculture, considered a threat to biodiversity with impacts on species richness and abundance (e.g., [76]). This process has led to unprecedented rates of local species extinctions [81].

Environmental impacts of agricultural intensification have been even more serious in Central and Eastern Europe because of collectivization of agricultural land and central management with no regard for place-specific conditions. For instance, large collective open fields have been created, heavy machinery has been used, and small landscape elements (e.g., wet meadows around springs, solitary trees, and small tree groups) have been progressively destroyed in the Czech Republic [134]. The scale of agriculture enlargement (small private fields have been joined into large collective ones), the turning of wetlands, meadows, and hedgerows into arable land, and the intensive use of chemicals has led to a loss of biological and landscape diversity, increasing water and soil pollution, soil erosion, and loss of cultural heritage [135]. The microstructure of landscapes also recorded great changes during the communist period due to irrigation and drainage measures, windbreaks, and non-rural buildings in the countryside. Landowners and farmers have embodied very different needs and demands in more recent times, and a progressively lower interest of leaseholders in maintaining high quality agricultural soils has become more and more evident [136].

The intensification of agriculture often means the simplification of landscape structures, creating large fields with a lack of small landscape elements such as hedgerows, forest boundaries, scattered trees, grass stripes, and small wetlands. Land-use patches are getting bigger and bigger, leading to a progressive landscape homogenization and low diversification of both natural and anthropogenic landscapes [137]. Such changes cause a drastic decline in traditional landscapes [47] and alter composition, connectivity, and configuration of natural habitats, with a decline in ecological stability. Major problems are also the loss in scattered trees and degradation of semi-natural landscape features with high natural value [28].

Changes in land use, especially agricultural intensification and forest clearcutting can lead to soil erosion [138]. Finally, it is widely known that land use influences water regimes. Landscape water potential (LWP) has been proposed as a basic characteristic of landscape elements centered on real evapotranspiration [105], which is mainly influenced by habitat types and their management [123,139]. Decrease in water areas, wetlands, forests, and grasslands, and their replacement by arable land is negative in terms of flood protection, water retention, and its accumulation in the landscape, determining a lower ecological stability. A significant decrease in wetlands in Czech lowlands (from nearly $30 \%$ to only $3.5 \%$ since the end of the eighteenth century till now) is related to losses in water absorption capacity [140]. Such changes have influenced all components of the water regime [53].

\subsubsection{Soil Fertilization and Use of Pesticides}

One of the most important factors causing biodiversity loss is the high level of soil fertilization [61] associated with a rapid decrease in aboveground diversity and reduction of underground diversity at higher levels of fertilization. Nutrient addition negatively impacts community richness and diversity in mesic grasslands [141-143] due to increased grass biomass and the accompanying reduction of light $[144,145]$. This loss of diversity can lower ecosystem stability over time [75]. Also, nutrient additions in tall-grass prairies lead to community variability, increased dominance, and reduced diversity, resulting in a progressive loss of ecosystem stability [84]. This process also eliminates the positive effect of earthworms [146], which causes a lower efficiency of nitrogen fertilization. The use of fungicides has an enormous effect on farm biodiversity, next to fertilization, grazing, and mowing regimes [147]. At the same time, use of pesticides and antibiotics plays a significant role. Insecticides have reduced diversity of insects, endangering crucial ecosystem functions such as pollination [148]. Weeds are controlled with herbicides and natural pest control is used exceptionally [61]. As crop 
production primarily depends on readily available fertilizers, soil processes for nutrient supply play only a marginal role. There is a high risk of soil quality depletion in the long-term. Because natural ecosystem functions are not used, there is a high degree of dependence on external inputs. Feedback controls balancing the system and minimizing production loss lead to increased dependency on external resources and reduced agro-ecosystem stability.

\subsubsection{Use of Heavy Machinery}

Heavy machinery causes compaction of soil and the loss of suitable soil characteristics, reducing infiltration capacity $[149,150]$. Soil compaction causes an overall decline in soil fertility decline. Because soil quality is a key variable assuring agro-ecosystem stability, unsustainable agronomic practices are endangering landscape stability.

\subsubsection{Irrigation and Drainage}

Croplands with water deficit have been more or less intensively irrigated. Irrigation is not only a serious driver of water consumption $[129,140,151]$ but can also cause salinization of soils, leading to biomass reduction and susceptibility to erosion [152]. Construction of massive drainage systems in wetlands and wet meadows has been observed in Czech Republic, mainly in the 1970s and the 1980s [153]. These transformations damaged natural habitats, negatively affecting water regimes, balance of nutrients, water-influenced energy dissipation, and landscape functionality.

\subsubsection{Intensification of Grazing}

Grazing by domestic livestock affects vegetation, soils, and hydrology [154] and impacts soils in a similar way to agricultural machinery, determining structural deformation (particularly under wet conditions) and soil compaction [149]. Soil compaction reduces the infiltration capacity of a soil $[149,150]$ and promotes surface runoff [155]. A decreasing vegetation cover due to overgrazing causes accelerated soil erosion [156,157] and reduces significantly soil water storage capacity, with the consequent depletion of water resources. All these consequences negatively affect biodiversity and ecosystem stability.

\subsection{Abandonment of Agricultural Land}

Agricultural abandonment is one of the major drivers of change in rural landscapes of temperate regions because of increasing yields on productive land, conservation policies, and the increasing imports of agricultural products from other regions, as well as changing political, economic, and social conditions. According to a remote sensing analysis, a total of 46.1 Mha of permanently fallow land has been detected in Europe, much of which may be linked to abandonment that occurred after the dissolution of the Eastern Bloc [158]. Up to 7.6 Mha of farmland was additionally abandoned from 001 to 2012, mainly in Eastern Europe, southern Scandinavia, and Europe's mountain regions.

Land abandonment occurs mainly in marginal areas where crop production is less viable from an economic perspective because of the areas' remote location or physical or climatic handicap [159-161], displaying a low level of competitiveness with respect to areas which have more favorable conditions [137]. Land abandonment has often paralleled agricultural intensification in more fertile locations. Low-intensity agricultural areas are mostly situated in mountainous districts and experience progressive marginalization, extensification, and abandonment, resulting in shrub and tree encroachments into old pastures and traditionally cultivated land [147]. Processes of abandonment involve different patterns of change, from partial abandonment creating a landscape mosaic of less and more used areas for cropping [162], to a progressive transformation toward uncultivated land [160].

The consequences of land abandonment for landscape diversity are not yet fully understood [163]. The effect of land abandonment on ecological stability can be positive or negative, depending mainly on the type and intensity of original land use [11], landscape type (especially the landscape matrix), and patterns of changes. Under certain conditions, land abandonment may lead to natural restoration 
of close-to-natural vegetation by process of spontaneous succession $[3,164]$. While it is reasonable to assume that vegetation processes contribute to the naturalization of the landscape, a more strict control on re-vegetation processes aimed at retrieving abandoned land with productive purposes (e.g., extensive livestock and leisure) is strongly encouraged to address environmental objectives (e.g., reduction of wildfires and increasing biodiversity) and cultural landscape preservation.

\subsubsection{Increase of Semi-Natural Vegetation and Ecosystem Functions}

Land abandonment triggers an increase in semi-natural vegetation types like scrubland and woodland [162]. Agricultural and pastoral abandonment has therefore been stressed as an opportunity for re-wilding European landscapes, with potentially broader ecological benefits for both nature conservation and the provision of ecosystem services at continental and regional scales $[9,159]$. This increase in landscape stability is related to abandonment of arable land, especially in areas exposed to soil erosion. The positive effects of land abandonment in terms of re-vegetation processes have been outlined [63], and these effects result in better erosion control and carbon sequestration. Abandoned field development of shrub layers and increase in vegetated patches over a long time have also been demonstrated to positively influence landscape stability, infiltration, and nutrient cycling at the local scale [165]. In Switzerland, forestation of formerly open land led to a short-term increase in species richness (due to increased landscape heterogeneity), even if causing the loss of habitats for open land species [166]. Beneficial effects of land abandonment on biodiversity were finally observed in rural landscapes with intense cropland in England [162].

Scrub and forest encroachment are also known to alter water cycle regulation and the downstream provision of hydrological ecosystem services, namely by reducing total runoff [167]. In the Czech Republic, land abandonment started with the decline of the communist regime in the late 1980s, in connection with the rehabilitation of a regime of private land ownership in the following decade. Land abandonment has occurred mainly in "less favored areas" (LFA) where environmental and ecological conditions discourage agriculture [135] and has resulted mainly in shrub and forest development as well as in the expansion of permanent grassland cover [107]. In some cases, arable land abandonment has compensated negative for the effects of previous agriculture intensification, mainly soil erosion in hilly areas.

\subsubsection{Loss of Natural Habitats and Biodiversity}

Because of a long history of human management, many of the most valued habitat types and biodiversity assets in Europe (especially semi-natural grasslands [168]) are currently dependent to some extent on the maintenance of sustainable farming systems [8]. Vegetation succession on abandoned land results in habitat modifications and ultimately leads to the loss of grassland and other open habitats due to overgrowth by shrubs and trees [27] or overgrowth by more competitive species, such as Phragmites australis, as in the case of wet grasslands [169]. This process negatively impacts landscape heterogeneity [170,171], plant richness [172], habitat diversity [169], determining habitat homogenization and loss of valuable species [11].

For instance, Mediterranean mountain areas have undergone human depopulation and abandonment of traditional practices, leading to land-use change and huge modification of landscape mosaics. Forests replacing cultivated land have altered floristic composition compared to the original vegetation, which brings about modification of the structure, stand density, and regeneration capacity. This process has altered ecosystem functionality and resilience, sometimes promoting wildfires and in turn leading to changes in soil quality that have enhanced erosion and land degradation [173]. In the Czech Republic, abandonment has occurred mainly in less suitable areas for agriculture, i.e., in mountain and sub-mountain landscapes. Many of these grasslands had been used as extensive meadows and pastures with long continuity of management and high diversity of species. Their abandonment has led to soil degradation, a decrease in species diversity, and decline of landscape heterogeneity. 


\subsection{Urbanization}

European cities expanded considerably in the 1950s and 1960s and are expected to grow further owing to increasing populations and transformation of rural settlements into urban centers. In post-communist European countries, urbanization was one of the most relevant drivers' trends of land-use change. The post-communist period was also characterized by a substantial reduction of agricultural land, making landscapes more vulnerable to different market interests [136]. In this regard, local development was associated with (more or less) subtle forms of suburban expansion and infrastructural development [153]. Urban expansion has both direct and indirect negative effects on the environment. The direct effects consist of a physical loss of agricultural land, natural habitats, and cultural landscapes. The indirect effects are mostly related to surface sealing (responsible for alteration of the hydrological cycle, increased run-off and soil erosion, and point contamination), landscape fragmentation [47], and biodiversity decline [174].

Urbanization has a negative impact on ecosystem functions and services, namely, water-retention, erosion protection, temperature regulation, and other issues. Long-term urbanization processes may thus have a negative impact on landscape resilience and ecosystem stability [2]. This is especially true in regions undergoing climate change (e.g., increasing aridity, local warming, and extreme weather events may arise) and those subject to a particularly high human pressure [63]. Urbanization also transforms composition and functioning of the adjacent land, causing ecological disturbances rarely encountered in pristine landscapes [19;26]. For instance, grassland fragments in urban areas are often considered to have a reduced level of plant biodiversity and more simplified ecological functions with respect to undisturbed, untransformed, and more 'natural' exurban grasslands [175]. Urbanization-driven alteration of biodiversity and habitats may also create novel ecosystems characterized by an increased number of exotic or alien species, modified resource and energy pathways, more compact artificial structures, and impervious surfaces [18].

Management of relict patches of natural vegetation in urban and peri-urban areas is frequently subjected to extensive transformations (e.g., into more intensive mowing and with removal of biomass), and these changes may result in a further decline of ecological stability. For instance, vegetation removal may decrease fine-scale landscape heterogeneity, resulting in soils which are more susceptible to crust formation, erosion, and compaction, limiting the soil infiltration capacity and causing depleted soil nutrient concentrations [176]. This in turn results in increased runoff and further erosion and affects soil surface stability of urban landscapes. Less available litter results in disrupted or diminished nutrient cycles. In urban areas, leaf litter has been demonstrated to be of poorer carbon quality and has been found to decompose and nitrify at quicker rates due to ecological stresses such as air pollution, the presence of heavy metals in soils, and the urban heat island effect [177]. Together with agricultural intensification, urbanization has finally determined a decline in pollinator species [175]. Open flower species and their specific flower-visitors are especially sensitive to increasing urbanization, which leads to lower reproductive success of plant communities [178], and, consequently, to a progressive loss of functional diversity, which is reflected in declining ecosystem functions and services [179].

\section{Discussion}

Despite the common use of an ecosystem stability definition [34], approaches and concepts of landscape stability adopted for operational purposes, including assessment of stability conditions and perturbing factors, vary to a great extent when focusing on various features which depend on the intimate characteristics of landscapes, e.g., soil stability, land-use structure, species composition, biodiversity, and ecosystem services. With respect to different concepts of landscape stability, focusing on single parts of the interconnected, complex system of properties, prerequisites and basic conditions, the indicators adopted for evaluation of landscape stability differ as well, partly due to different scales or landscape types to which they are applied. We can also distinguish indicators quantifying factors considered to be prerequisites of landscape stability (e.g., ecological and socioeconomic features that promote stability) and indicators assessing changes over time in landscape stability (e.g., declining 
stability), which can be further divided into indicators evaluating stability drivers and (apparent or subtle) changes in the response of ecological systems to disturbance [180]. Based on the reviewed literature, this study has grouped the candidate indicators into main domains concerning natural habitat characteristics, landscape metrics (connectivity/fragmentation), thermodynamic variables, functional indicators, biodiversity, soil degradation, ecological disturbances, and land-use/land cover change. In order to explore the connection between land-use change and loss in landscape stability, we have focused on the three most important land-use and land cover changes that are at the same time the most threatening for landscape stability (agricultural intensification, land abandonment, and urbanization), and we have tried to summarize the main factors and principles through which such reduction is occurring [181].

Agricultural intensification assumes various forms, including transformation of highly diversified mosaics to low-diversity arable land determining a progressive loss of small landscape elements, which weakens stability and negatively impacts landscape configuration, water regimes, and soil erosion. Cropland intensification also includes use of fertilizers and pesticides, which has the main effects of biodiversity decline, use of heavy machinery that lends threats to soil quality, water regime manipulation that endangers water availability, changes in soil quality and biodiversity, and grazing intensification that affects vegetation with a consequent decrease in soil stability and water regime performance [128].

Abandonment of agricultural land can have both positive and negative impacts on landscape stability [182]. Positive effects are observed, for instance, on arable land, where land abandonment contributes to restoring and enhancing basic ecosystem functions through vegetation expansion, often with semi-natural characters. Negative effects are mostly observed in extensive, traditionally managed meadows and pastures, which have changed from valuable and high-diversity habitats into fragmented mosaics of ruderal lawns and bushes. Urbanization finally causes habitat loss, landscape fragmentation, reduced performances of ecosystem functions (mainly water retention), erosion protection, and temperature regulation. It can also cause increased stress to adjacent areas and soil degradation [84].

While a wealth of studies has been devoted to investigating ecological stability and disturbance regimes, literature gaps concern the definition of landscape stability and the identification of contextual prerequisites and consequences of disturbance from a landscape perspective. According to [6], "the various definitions of stability have themselves not been connected and correlated", which is barely true also for a variety of indicators adopted for a comprehensive assessment of landscape stability. For instance, while the negative effects of land-use change are connected to specific aspects of ecological stability and its possible decline over time, a direct quantification of such effects is still partial. Understanding thresholds in the rapidity of land-use change threatening complex socio-environmental systems has not yet been completely developed [183]. Moreover, ecological processes and relationships may differ across various landscape types and each of them has different aspects which are crucial for landscape stability assessment [57].

What are the strengths and weaknesses of each landscape type (in relation to ecological stability) and what are the relevant indicators? How can we define the thresholds and apply them to manage and plan present and future land-use structures with the aim to avoid a decline in ecosystem services? These questions remain not sufficiently answered yet. As mentioned in [184], ecological complexity when developing adaptation strategies, the multidisciplinary nature of adaptive management of ecosystems, and knowledge gaps existing when translating the biophysical information into adaptation strategies may limit our understanding of 'how to adapt' with regards to ecosystems.

An integrated framework is needed that connects and correlates various definitions of landscape stability and links these to the underlying properties of ecological systems [29]. This would need robust specification of the relationships between land-use change and several dimensions of landscape stability. Based on these relationships, original frameworks can be proposed to predict the reaction of landscape stability to expected (or even unexpected) land-use change (e.g., under climate change) 
and to set thresholds in land use which would serve as limits for landscape planning. In this regard, any land patch may have a high resilience based on criteria affecting hydrological processes but low resilience in the case that criteria are based on another ecological function, e.g., primary biomass production [12]. As an operational solution, a framework that works with landscape types (according, at least, to some general typologies) may allow for a more comprehensive assessment of landscape-level specific risks related to (more or less rapid) depletion of ecological conditions leading to (high or low) stability. While landscape stability can be assessed according to different methods and analysis dimensions, comparison of outcomes from various approaches applied to different landscape types definitely contributes to identification of the most relevant aspects, criteria, thresholds, and feedback relationships underlying the stability of each landscape type.

\section{Conclusions}

Based on the results of the present study, additional research should envision innovative frameworks to shed light on the intimate mechanisms underlying landscape stability and to indicate new approaches to stability assessment for different landscape types. By identifying strengths and weaknesses of different ecological systems as far as landscape stability properties is concerned, further investigation should address the relationship between land-use change and ecological stability, defining thresholds beyond which irreversible land degradation processes might occur. This will help to identify critical thresholds of land-use change that may contain (or prevent) threats to landscape stability. New assessment methodologies should finally take greater account of the increasing sensitivity of species and communities to climate change.

Author Contributions: Conceptualization, P.C. and L.S.; methodology, O.C. and M.P.; investigation, A.C.; resources, R.P.; data curation, R.V.; writing—original draft preparation, M.P. and P.C.; writing-review and editing, L.S.; visualization, G.E.; supervision, R.P.; project administration, R.V.; funding acquisition, G.E.

Funding: This work was supported by the Ministry of Education, Youth and Sports of Czech Republic within the National Sustainability Program I (NPU I), no. LO1415.

Conflicts of Interest: The authors declare no conflict of interest.

\section{References}

1. Adger, W.N. Vulnerability. Glob. Environ. Chang. 2006, 16, 268-281. [CrossRef]

2. Antrop, M. Why landscapes of the past are important for the future. Landsc. Urban Plan. 2005, 70, 21-34. [CrossRef]

3. Cramer, V.A.; Hobbs, R.J.; Standish, R.J. What's new about old fields? Land abandonment and ecosystem assembly. Trends Ecol. Evol. 2008, 23, 104-112. [CrossRef] [PubMed]

4. Cuttler, S.L.; Barnes, L.; Berry, M.; Burton, C.; Evans, E.; Tate, E.; Webb, J. A place-based model for understanding community resilience to natural disasters. Glob. Environ. Chang. 2008, 18, 598-606. [CrossRef]

5. Duffy, A. Biodiversity and ecosystem function: The consumer connection. Oikos 2002, 99, 201-219. [CrossRef]

6. Feng, W.; Bailey, R.M. Unifying relationships between complexity and stability in mutualistic ecological communities. J. Theor. Biol. 2018, 439, 100-126. [CrossRef] [PubMed]

7. Gehrig-Fasel, J.; Guisan, A.; Zimmermann, N.E. Tree line shifts in the Swiss Alps: Climate change or land abandonment? J. Veg. Sci. 2007, 18, 571-582. [CrossRef]

8. Halada, L.; Evans, D.; Romao, C.; Petersen, J.-E. Which habitats of European importance depend on agricultural practices? Biodivers. Conserv. 2011, 20, 2365-2378. [CrossRef]

9. Henle, K.; Alard, D.; Clitherow, J.; Cobb, P. Identifying and managing the conflicts between agriculture and biodiversity conservation in Europe-A review. Agric. Ecosyst. Environ. 2008, 124, 60-71. [CrossRef]

10. Holt-Giménez, E. Measuring farmers' agroecological resistance after Hurricane Mitch in Nicaragua: A case study in participatory, sustainable land management impact monitoring. Agric. Ecosyst. Environ. 2002, 93, 87-105. [CrossRef] 
11. Honrado, J.P.; Lomba, A.; Alves, P.; Aguiar, C.; Monteiro-Henriques, T.; Cerqueira, Y.; Monteiro, P.; Barreto Caldas, F. Conservation Management of EU Priority Habitats after Collapse of Traditional Pastoralism: Navigating Socioecological Transitions in Mountain Rangeland. Rural Sociol. 2017, 82, 101-128. [CrossRef]

12. Kosmas, C.; Karamesouti, M.; Kounalaki, K.; Detsis, V.; Vassiliou, P.; Salvati, L. Land degradation and long-term changes in agro-pastoral systems: An empirical analysis of ecological resilience in Asteroussia-Crete (Greece). Catena 2016, 147, 196-204. [CrossRef]

13. Lavorel, S. Guest editorial: Global change effects on landscape and regional patterns of plant diversity. Divers. Distrib. 1999, 5, 239-240. [CrossRef]

14. Lavorel, S.; Colloff, M.J.; Mcintyre, S.; Doherty, M.D.; Murphy, H.T.; Metcalfe, D.J.; Dunlop, M.; Williams, M.J.; Wise, R.M.; Williams, K.J. Ecological mechanisms underpinning climate adaptation services. Glob. Chang. Biol. 2015, 151, 23-29. [CrossRef] [PubMed]

15. Lee, S.; Yeo, I.-Y.; Lang, M.W.; Sadegi, A.M.; McCarty, G.W.; Moglen, G.E.; Evenson, G.R. Assessing the cumulative impacts of geographically isolated wetlands on watershed hydrology using the SWAT model coupled with improved wetland modules. J. Environ. Manag. 2018, 223, 37-48. [CrossRef] [PubMed]

16. Lin, B.B. Resilience in Agriculture through Crop Diversification: Adaptive Management for Environmental Change. BioScience 2011, 61, 183-193. [CrossRef]

17. Marignani, M.; Rocchini, D.; Torri, D.; Chiarucci, A.; Maccherini, S. Planning restoration in a cultural landscape in Italy using an object-based approach and historical analysis. Landsc. Urban Plan. 2008, 84, 28-37. [CrossRef]

18. Niemela, J. Is there a need for a theory of urban ecology? Urban Ecosyst. 1999, 3, 57-65. [CrossRef]

19. Niemela, J.; Breuste, J.; Elmqvist, T.; Gutenspergen, G.; James, P.; McIntyre, N. Urban Ecology Patterns, Processes, and Applications; Oxford University Press: Oxford, UK, 2011.

20. O’Neill, R.V.; Krummel, J.R.; Gardner, R.H.; Sugihara, G.; Jackson, B.; DeAngelis, D.L.; Milne, B.T.; Turner, M.G.; Zygmunt, B.; Christensen, S.W.; et al. Indices of landscape pattern. Landsc. Ecol. 1988, 1, 153-162. [CrossRef]

21. Odum, H.T. Self-organization, Transformity and Information. Science 1988, 242, 1132-1139. [CrossRef] [PubMed]

22. Odum, H.T. Simulation and evaluation with energy systems blocks. Ecol. Model. 1996, 93, 155-173. [CrossRef]

23. Oliver, T.H.; Isaac, J.B.; August, T.A.; Woodcock, B.A.; Roy, D.B.; Bullock, J.M. Declining resilience of ecosystem functions under biodiversity loss. Nat. Commun. 2015, 6, 10122. [CrossRef] [PubMed]

24. O'Neill, R.V.; Johnson, A.R.; King, A.W. A hierarchical framework for the analysis of scale. Landsc. Ecol. 1989, 3, 193-205. [CrossRef]

25. Parcerisas, L.; Marull, J.; Pino, J.; Tello, E.; Coll, F.; Basnau, C. Land use changes, landscape ecology and their socioeconomic driving forces in the Spanish Mediterranean coast (El Maresme County, 1850-2005). Environ. Sci. Policy 2012, 23, 120-132. [CrossRef]

26. Pickett, S.T.A.; Cadenasso, M.L.; Grove, J.M.; Boone, C.G.; Groffman, P.M.; Irwin, E.; Kaushal, S.S.; Mashall, V.; McGrath, B.P.; Nilon, C.H.; et al. Urban ecological systems: Scientific foundations and a decade of progress. J. Environ. Manag. 2011, 92, 331-362. [CrossRef] [PubMed]

27. Plieninger, T. Habitat loss, fragmentation, and alteration-quantifying the impact of land-use changes on a Spanish dehesa landscape by use of aerial photography and GIS. Landsc. Ecol. 2006, 21, 91-105. [CrossRef]

28. Plieninger, T. Monitoring directions and rates of change in trees outside forests through multitemporal analysis of map sequences. Appl. Geogr. 2012, 32, 566-576. [CrossRef]

29. Ives, A.R.; Carpenter, S.R. Stability and diversity of ecosystems. Science 2007, 317, 58-62. [CrossRef] [PubMed]

30. Turner, M.G.; Romme, W.H.; Gardner, R.H.; O'Neill, R.V.; Kratz, T. A revised concept of landscape equilibrium: Disturbance and stability on scaled landscapes. Landsc. Ecol. 1993, 8, 213-227. [CrossRef]

31. Walker, B.; Holling, C.S.; Carpenter, S.R. Resilience, adaptability and transformability in social-ecological systems. Ecol. Soc. 2004, 9, 5. [CrossRef]

32. Walker, B.; Salt, D.; Reid, W. Resilience Thinking Sustaining People and Ecosystems in a Changing World; Island Press: Washington, DC, USA, 2006.

33. Walker, B. Conserving biological diversity through ecosystem resilience. Conserv. Biol. 1995, 9, 747-752. [CrossRef]

34. Holling, C.S. Resilience and stability of ecological systems. Annu. Rev. Ecol. Syst. 1973, 4, 1-23. [CrossRef] 
35. Folke, C. Resilience: The emergence of a perspective for social-ecological systems analyses. Glob. Environ. Chang. 2006, 16, 253-267. [CrossRef]

36. Carpenter, S.R.; Brock, W.A. Adaptive capacity and traps. Ecol. Soc. 2008, 13, 1-16. [CrossRef]

37. Carpenter, S.; Walker, B.; Anderies, J. From Metaphor to Measurement: Resilience of What to What? Ecosystems 2001, 4, 765. [CrossRef]

38. Holling, C.S. Understanding the complexity of economic, ecological, and social systems. Ecosystems 2001, 4, 390-405. [CrossRef]

39. Folke, C.; Carpenter, S.; Walker, B.; Scheffer, M.; Chapin, T.; Rockström, J. Resilience Thinking: Integrating Resilience, Adaptability and Transformability. Ecol. Soc. 2010, 15. [CrossRef]

40. Folke, C.; Carpenter, S.; Walker, B.; Scheffer, M.; Elmquist, T.; Gunderson, L.; Holling, C.S. Regime Shifts, Resilience, and Biodiversity in Ecosystem Management. Annu. Rev. Ecol. Evol. Syst. 2004, 35, 557-581. [CrossRef]

41. Berardi, G.; Green, R.; Hammond, B. Stability, sustainability, and catastrophe: Applying resilience thinking to US agriculture. Hum. Ecol. Rev. 2011, 18, 115-125.

42. Loucks, O.L. The United States' IBP: An ecosystems perspective after fifteen years. In Ecosystem Theory and Application; Polunin, N., Ed.; John Wiley Sons: New York, NY, USA, 1986; pp. 390-405.

43. Patten, B.C.; Odum, E.P. The Cybernetic Nature of Ecosystems. Am. Nat. 1981, 118, 886-895. [CrossRef]

44. Wu, J.G.; Loucks, O.L. From balance of nature to hierarchical patch dynamics: A paradigm shift in ecology. Q. Rev. Biol. 1995, 70, 439-466. [CrossRef]

45. $\mathrm{Wu}, \mathrm{J} . ; \mathrm{Wu}, \mathrm{T}$. Ecological resilience as a foundation for urban design and sustainability. In Resilience in Ecology and Urban Design. Future City; Pickett, S., Cadenasso, M., McGrath, B., Eds.; Springer: Dordrecht, The Netherlands, 2013; Volume 3.

46. Zurlini, G.; Petrosillo, I.; Jones, B.; Zaccarelli, N. Highlighting order and disorder in social-ecological landscapes to foster adaptive capacity and sustainability. Landsc. Ecol. 2013, 28, 1161-1173. [CrossRef]

47. Frondoni, R.; Mollo, B.; Capotorti, G. A landscape analysis of land cover change in the municipality of Rome (Italy): Spatio-temporal characteristicks and ecological implications of land cover transition from 1954 to 2001. Landsc. Urban Plan. 2011, 100, 117-128. [CrossRef]

48. Wang, D.; Gong, J.; Chen, L.; Zhang, L.; Song, Y.; Yue, Y. Comparative analysis of land use/cover change trajectories and their driving forces in two small watersheds in the western Loess Plateau of China. Int. J. Appl. Earth Obs. Geoinf. 2013, 21, 241-252. [CrossRef]

49. Käyhkö, N.; Skånes, H. Change trajectories and key biotopes-Assessing landscape dynamics and sustainability. Landsc. Urban Plan. 2006, 75, 300-321. [CrossRef]

50. Pitkänen, T.P.; Kumpulainen, J.; Lehtinen, J.; Sihvonen, M.; Käyhkö, N. Landscape history improves detection of marginal habitats on semi-natural grasslands. Sci. Total Environ. 2016, 539, 359-369. [CrossRef]

51. Kubeš, J. Biocentres and corridors in a cultural landscape. A critical assessment of the 'territorial system of ecological stability'. Landsc. Urban Plan. 1996, 35, 231-240.

52. Lipsky, Z. The changing face of the Czech rural landscape. Landsc. Urban Plan. 1995, 31, 39-45. [CrossRef]

53. Lipský, Z.; Demková, K.; Skaloš, J.; Kukla, P. The influence of natural conditions on changes in landscape use: A case study of the Lower Podoubraví region (Czech Republic). Ekológia 2011, 30, 239-256.

54. Kremen, C.; Ostfeld, R.S. A call to ecologists: Measuring, analyzing, and managing ecosystem services. Front. Ecol. Environ. 2005, 3, 540-548. [CrossRef]

55. Kremen, C.; Williams, N.M.; Thorp, R.W. Crop pollination from native bees at risk from agricultural intensification. Proc. Natl. Acad. Sci. USA 2002, 99, 16812-16816. [CrossRef]

56. Van Andel, T.H.; Zangger, E.; Demitrack, A. Land use and soil erosion in prehistoric and historical Greece. J. Field Archaeol. 2013, 17, 379-396.

57. Kairis, O.; Karavitis, C.; Kounalaki, A.; Salvati, L.; Kosmas, C. The effect of land management practices on soil erosion and land desertification in an olive grove. Soil Use Manag. 2013, 29, 597-606. [CrossRef]

58. Kairis, O.; Karavitis, C.; Salvati, L.; Kounalaki, A.; Kosmas, K. Exploring the impact of overgrazing on soil erosion and land degradation in a dry Mediterranean agro-forest landscape (Crete, Greece). Arid Land Res. Manag. 2015, 29, 360-374. [CrossRef]

59. Karamesouti, M.; Detsis, V.; Kounalaki, A.; Vasiliou, P.; Salvati, L.; Kosmas, C. Land-use and land degradation processes affecting soil resources: Evidence from a traditional Mediterranean cropland (Greece). Catena 2015, 132, 45-55. [CrossRef] 
60. Salvati, L.; Ferrara, C.; Corona, P. Indirect validation of the Environmental Sensitive Area Index using soil degradation indicators: A country-scale approach. Ecol. Indic. 2015, 57, 360-365. [CrossRef]

61. Erisman, J.W.; van Eekeren, N.; de Wit, J.; Koopmans, C.; Cuijpers, W.; Oerlemans, N.; Koks, B.J. Agriculture and biodiversity: A better balance benefit both. AIMS Agric. Food 2016, 1, 157-174. [CrossRef]

62. Amundson, R.; Asmeret Asefaw, B.A.A.; Hopmans, J.W.; Olson, C.; Ester Sztein, A.; Sparks, D.L. Soil science. Soil and human security in the 21st century. Science 2015, 348, 1261071. [CrossRef]

63. Salvati, L.; Perini, L.; Bajocco, S.; Sabbi, A. Climate aridity and land use change: A regional-scale analysis. Geogr. Res. 2012, 50, 193-203. [CrossRef]

64. Salvati, L.; Zitti, M.; Perini, L. Fifty years on: Long-term patterns of land sensitivity to desertification in Italy. Land Degrad. Dev. 2016, 27, 97-107. [CrossRef]

65. Fischer, J.; Lindenmayer, D.B.; Manning, A.D. Biodiversity, ecosystem function, and resilience: Ten guiding principles for commodity production landscapes. Front. Ecol. Environ. 2006, 4, 80-86. [CrossRef]

66. Huyghe, C.; Litrico, I.; Surault, F. Agronomic value and provisioning services of multi-species swards. Grassl Sci Eur 2012, 17, 35-46.

67. Brown, J.H. Complex ecological systems. In Complexity: Metaphores, Models, and Reality; Cowan, G.A., Pines, D., Meltzer, D., Eds.; Westview: Boulder, CO, USA, 1994; pp. 419-449.

68. Reusch, T.B.H.; Ehlers, A.; Hämmerli, A.; Worm, B. Ecosystem recovery after climatic extremes enhanced by genotypic diversity. Proc. Natl. Acad. Sci. USA 2005, 102, 2826-2831. [CrossRef]

69. Sgrò, C.M. Building evolutionary resilience for conserving biodiversity under climate change. Ecol. Appl. 2011, 4, 326-337. [CrossRef]

70. Jacobsen, S.E.; Sørensen, M.; Pedersen, S. Feeding the world: Genetically modified crops versus agricultural biodiversity. Agron. Sustain. Dev. 2013, 33, 651-662. [CrossRef]

71. Swift, T.L.; Hannon, S.J. Critical thresholds associated with habitat loss: A review of the concepts, evidence, and applications. Biol. Rev. 2010, 85, 35-53. [CrossRef]

72. Vandermeer, J.; van Noordwijk, M.; Anderson, J. Global change and multi-species agroecosystems: Concepts and issues. Agric. Ecosyst. Environ. 1998, 67, 1-22. [CrossRef]

73. Jankauskas, B.; Jankauskiene, G. Erosion-preventivecrop rotations for landscape ecological stability in uplandregions of Lithuania. Agric. Ecosyst. Environ. 2006, 95, 129-142. [CrossRef]

74. Mundt, C.C. Use of multiline cultivars and cultivar mixtures for disease management. Annu. Rev. Phytopathol. 2002, 40, 381-410. [CrossRef]

75. Tilman, D. Biodiversity: Population versus ecosystem stability. Ecology 1996, 77, 350-363. [CrossRef]

76. Tilman, D.; Fargione, J.; Wolff, B.; D'Antonio, C.; Dobson, A.; Howarth, R.; Schindler, D.; Schlesinger, H.; Simberloff, D.; Swackhamer, D. Forecasting Agriculturally Driven Global Environmental Change. Science 2001, 292, 281-284. [CrossRef]

77. Tilman, D.; Hill, J.; Lehman, C. Carbon-negative biofuels from low-input high-diversity grassland biomass. Science 2006, 314, 1598-1600. [CrossRef]

78. Stein, A. Environmental heterogeneity as a universal driver of species richness across taxa, biomes and spatial scales. Ecol. Lett. 2014, 17, 866-880. [CrossRef]

79. Pearson, D.M.; Gorman, J.T. Managing the landscapes of the Australian Northern Territory for sustainability: Visions, issues and strategies for successful planning. Future 2010, 42, 711-722. [CrossRef]

80. Díaz, S.; Purvis, A.; Cornelissen, J.H.C.; Mace, G.M.; Donoghue, M.J.; Ewers, R.M.; Pearse, W.D. Functional traits, the phylogeny of function, and ecosystem service vulnerability. Ecol. Evol. 2013, 3, 2958-2975. [CrossRef]

81. Hodgson, J.A. Habitat area, quality and connectivity: Striking the balance for efficient conservation. J. Appl. Ecol. 2011, 48, 148-152. [CrossRef]

82. Hodgson, J.G.; Grime, J.P.; Wilson, P.J.; Thompson, K.; Band, S.R. The impacts of agricultural change (1963-2003) on the grassland flora of Central England: Processes and prospects. Basic Appl. Ecol. 2005, 6, 107-118. [CrossRef]

83. Salvati, L. Agro-forest landscape and the 'fringe'city: A multivariate assessment of land-use changes in a sprawling region and implications for planning. Sci. Total Environ. 2014, 490, 715-723. [CrossRef]

84. Koerner, S.E.; Avolio, M.L.; La Pierre, K.J.; Wilcox, K.R.; Smith, M.D.; Collins, S.L. Nutrient additions cause divergence of tallgrass prairie plant communities resulting in loss of ecosystem stability. J. Ecol. 2016, 104, 1478-1487. [CrossRef] 
85. Gonthier, D.J.; Ennis, K.J.; Farinas, S. Biodiversity conservation in agriculture requires a multi-scale approach. Proc. R. Soc. B 2014, 281, 20141358. [CrossRef]

86. Smith, H.G.; Dänhardt, J.; Lindström, A. Consequences of organic farming and landscape heterogeneity for species richness and abundance of farmland birds. Oecologia 2010, 162, 1071-1079. [CrossRef]

87. Smith, R.G.; Gross, K.L.; Robertson, G.P. Effects of crop diversity on agroecosystem function: Crop yield response. Ecosystems 2008, 11,355-366. [CrossRef]

88. Rehačková, T.; Pauditšová, E. Methodical procedure to calculate the coefficient of ecological stability. Acta Environ. Univ. Comen. Bratisl. 2007, 15, 26-38.

89. Van Eetvelde, V.; Antrop, M. Indicators for assessing changing landscape character of cultural landscapes in Flanders (Belgium). Land Use Policy 2009, 26, 901-910. [CrossRef]

90. Jellema, A.; Stobbelaar, D.-J.; Groot, J.C.J.; Rossing, W.A.H. Landscape character assessment using region growing techniques in geographical information systems. J. Environ. Manag. 2009, 90, S161-S174. [CrossRef]

91. Ripl, W. Management of water cycle and energy flow for ecosystem control: The energy-transport-reaction (ETR) model. Ecol. Model. 1995, 78, 61-76. [CrossRef]

92. Freudenberger, L.; Hobson, P.R.; Schluck, M.; Ibisch, P.L. A global map of the functionality of terrestrial ecosystems. Ecol. Complex. 2012, 12, 13-22. [CrossRef]

93. Lee, Y.C.; Yeh, C.T.; Huang, S.L. Energy hierarchy and landscape sustainability. Landsc. Ecol. 2013, $28,1151$.

94. Jørgensen, S.E. Eco-Exergy as Sustainability; Wit Press: Southampton, UK, 2006.

95. Svirezhev, Y.M.; Steinborn, W. Exergy of solar radiation: Thermodynamic approach. Ecol. Model. 2001, 145, 101-110. [CrossRef]

96. Ulanowicz, R.E. Ascendancy: A measure of ekosystem performance. In Handbook of Ekosystém Theories and Management; Jorgensen, S.E., Muller, F., Eds.; CRC Press: Boca Raton, FL, USA, 2000; pp. 303-316.

97. Levin, S. Towards a Science of Ecological Management. Conserv. Ecol. 1999, 3, 6. [CrossRef]

98. Norris, C.; Hobson, P.; Ibisch, P.L. Microclimate and vegetation function as indicators of forest thermodynamic efficiency. J. Appl. Ecol. 2012, 49, 562-570. [CrossRef]

99. Ryan, J.G.; Ludwig, J.A.; McAlpine, C.A. Complex adaptive landscapes (CAL): A conceptual framework of multi-functional, non-linear ecohydrological feedback systems. Ecol. Complex. 2007, 4, 113-127. [CrossRef]

100. Muller, F. Indicating ecosystem and landscape organisation. Ecol. Indic. 2005, 5, 280-294. [CrossRef]

101. Silow, E.; Mokry, A.V. Exergy as a Tool for Ecosystem Health Assessment. Entropy 2010, 12, 902-925. [CrossRef]

102. Szargut, J. Exergy Method, Technical and Ecological Applications; WIT Press: Southampton, UK, 2005.

103. Zaccarelli, N.; Li, B.-L.; Petrosillo, I.; Zurlini, G. Order and disorder in ecological time-series: Introducing normalized spectral entropy. Ecol. Indic. 2012, 28, 22-30. [CrossRef]

104. Kirkby, M.J.; Le Bissonais, Y.; Coulthard, T.J.; Daroussin, J.; McMahon, M.D. The development of Land Quality Indicators for Soil Degradation by Water Erosion. Agric. Ecosyst. Environ. 2000, 81, 125-136. [CrossRef]

105. Skaloš, J.; Berchová, K.; Pokorný, J.; Sedmidubský, T.; Pecharová, E.; Trpáková, I. Landscape water potential as a new indicator for monitoring macrostructural landscape changes. Ecol. Indic. 2014, 36, 80-93. [CrossRef]

106. Skaloš, J.; Engstová, B. Methodology for mapping non-forest wood elements using historic cadastral maps and aerial photographs as a basis for management. J. Environ. Manag. 2010, 91, 831-843. [CrossRef]

107. Skaloš, J.; Weber, M.; Lipsky, Z.; Trpakova, I.; Šantrůčková, M.; Uhlírová, L.; Kukla, P. Using old military survey maps and orthophotograph maps to analyse long-term land cover changes: A Case study (Czech Republic). Appl. Geogr. 2011, 31, 426-438. [CrossRef]

108. Salvati, L.; Petitta, M.; Ceccarelli, T.; Perini, L.; Di Battista, F.; Scarascia, M.E.V. Italy's renewable water resources as estimated on the basis of the monthly water balance. Irrig. Drain. 2008, 57, 507-515. [CrossRef]

109. Colantoni, A.; Mavrakis, A.; Sorgi, T.; Salvati, L. Towards a 'polycentric' landscape? Reconnecting fragments into an integrated network of coastal forests in Rome. Rendiconti Lincei 2015, 26, 615-624. [CrossRef]

110. Hrabik, T.R.; Greenfield, B.K.; Lewis, D.B.; Pollard, A.I.; Wilson, K.A.; Kratzet, T.K. Landscape-scale variation in taxonomic diversity in four groups of aquatic organisms: The influence of physical, chemical, and biological properties. Ecosystems 2005, 8, 301-317. [CrossRef]

111. Wagner, H.H.; Wildi, O.; Ewald, K.C. Additive partitioning of plant species diversity in an agricultural mosaic landscape. Landsc. Ecol. 2000, 15, 219-227. [CrossRef]

112. Rocchini, D.; Andreini Butini, S.; Chiarucci, A. Maximizing plant species inventory efficiency by means of remotely sensed spectral distances. Glob. Ecol. Biogeogr. 2005, 14, 431-437. [CrossRef] 
113. Song, K.; Lu, S. Effect of hydraulic properties of soil and fluctuation velocity of reservoir water on landslide stability. Environ. Earth Sci. 2015, 74, 5319-5329. [CrossRef]

114. Van Apeldoorn, D.F.; Sonnenveld, M.P.W.; Kok, K. Landscape asymmetry of soil organic matter as a source of agro-ecosystem resilience. Agric. Ecosyst. Environ. 2011, 140, 401-410. [CrossRef]

115. Berzsenyi, Z.; Gyorffy, B.; Lap, D. Effect of crop rotation and fertilisation on maize and wheat yields and yield stability in a long-term experiment. Eur. J. Agron. 2000, 13, 225-244. [CrossRef]

116. Verhulst, N.; Carrillo-Garcia, A.; Moeller, C.; Trethowan, R.; Sayre, K.D.; Govaerts, B. Conservation agriculture for wheat-based cropping systems under gravity irrigation: Increasing resilience through improved soil quality. Plant Soil 2011, 340, 467-479. [CrossRef]

117. Trabaquini, K.; Formaggio, R.A.; Galvão, L.S. Changes in physical properties of soils with land use time in the Brazilian savanna environment. Land Degrad. Dev. 2015, 26, 397-408. [CrossRef]

118. Delmotte, S.; Tittonell, P.; Mouret, J.C.; Hammond, R.; Lopez-Ridaura, S. On farm assessment of rice yield variability and productivity gaps between organic and conventional cropping systems under Mediterranean climate. Eur. J. Agron. 2011, 35, 223-236. [CrossRef]

119. Mallory, E.B.; Porter, G.A. Potato yield stability under contrasting soil management strategies. Agron. J. 2007, 99, 501-510. [CrossRef]

120. Salvati, L.; Zitti, M. Land degradation in the Mediterranean basin: Linking bio-physical and economic factors into an ecological perspective. Biota 2005, 5, 67-77.

121. Bajocco, S.; De Angelis, A.; Salvati, L. A satellite-based green index as a proxy for vegetation cover quality in a Mediterranean region. Ecol. Indic. 2012, 23, 578-587. [CrossRef]

122. Khumairoh, U.; Groot, J.C.J.; Lantinga, E.A. Complex agro-ecosystems for food security in a changing climate. Ecol. Evol. 2012, 2, 1696-1704. [CrossRef]

123. Rockström, J.; Gordon, L.; Folke, C.; Falkenmark, M.; Engwall, M. Linkages Among Water Vapor Flows, Food Production, and Terrestrial Ecosystem Services. Conserv. Ecol. 1999, 3, 1-39. [CrossRef]

124. Peterson, C.A.; Eviner, V.T.; Gaudin, A.C.M. Ways forward for resilience research in agroecosystems. Agric. Syst. 2018, 162, 19-27. [CrossRef]

125. Busch, G. Future European agricultural landscapes-What can we learn from existing quantitative land use scenario studies? Agric. Ecosyst. Environ. 2006, 114, 121-140. [CrossRef]

126. Reitalu, T.; Purschke, O.; Johansson, J.; Hall, K.; Sykes, M.T.; Prentice, H.C. Responses of grassland species richness to local and landscape factors depend on spatial scale and habitat specialization. J. Veg. Sci. 2012, 23, 41-51. [CrossRef]

127. Cousins, S.A.O. Analysis of land-cover transitions based on 17th and 18th century cadastral maps and aerial photographs. Landsc. Ecol. 2001, 16, 41-54. [CrossRef]

128. Salvati, L.; Bajocco, S.; Ceccarelli, T.; Zitti, M.; Perini, L. Towards a process-based evaluation of land vulnerability to soil degradation in Italy. Ecol. Indic. 2011, 11, 1216-1227. [CrossRef]

129. Šantrůčková, M.; Demková, K.; Weber, M.; Lipský, Z.; Dostálek, J. Long-term changes in water areas and wetlands in an intensively farmed landscape: A case study from the Czech Republic. Eur. Countrys. 2017, 1, 132-144. [CrossRef]

130. European Environment Agency. European Ecosystem Assessment-Concept, Data, and Implementation. Contribution to Target 2 Action 5 Mapping and Assessment of Ecosystems and their Services (MAES) of the EU Biodiversity Strategy to 2020. EEA Technical Report no.6/2015; European Environment Agency: Copenhagen, Denmark, 2015.

131. Firbank, L.G.; Petit, S.; Smart, S.; Blain, A.; Fuller, R.J. Assessing the impacts of agricultural intensification on biodiversity: A British perspective. Philos. Trans. R. Soc. B 2008, 363, 777-787. [CrossRef]

132. Khoury, C.K.; Bjorkman, A.D.; Dempewolf, H.; Villegas, J.R.; Guarino, L.; Jarvis, A.; Rieseberg, L.H.; Struik, P.C. Increasing homogeneity in global food supplies and the implications for food security. Proc. Natl. Acad. Sci. USA 2014, 111, 4001-4006. [CrossRef]

133. Foley, J.A.; Ramankutty, N.; Brauman, K.A.; Cassidy, E.S.; Gerber, J.S.; Johnston, M. Solutions for a cultivated planet. Nature 2011, 478, 337-342. [CrossRef]

134. Grešlová, K. A case study of the Czech agriculture since 1918 in a socio-metabolic perspective-From land reform through nationalisation to privatisation. Land Use Policy 2013, 30, 592-603. [CrossRef]

135. Boucníková, E.; Kučera, T. How natural and cultural aspects influence land cover changes in the Czech Republic? Ekológia 2005, 24, 1-24. 
136. Št'astná, M.; Vaishar, A.; Stonawská, K. Integrated Transport System of the South-Moravian Region and its impact on rural development. Transp. Res. Part D Transp. Environ. 2015, 36, 53-64. [CrossRef]

137. Jongman, R.H.G. Homogenisation and fragmentation of the European landscape: Ecological consequences and solutions. Landsc. Urban Plan. 2002, 58, 211-221. [CrossRef]

138. Erdogan, E.H.; Pellikka, P.; Clark, B. Impact of land cover change on soil loss in the Taita Hills, Kenya between 1987 and 2003. Int. J. Remote Sens. 2011, 32, 5919-5945. [CrossRef]

139. Kedziora, A. Landscape management practices for maintanance and enhancement of ecosystem services in a countryside. Ecohydrol. Hydrobiol. 2010, 10, 133-152. [CrossRef]

140. Šantrůčková, M.; Dostálek, J.; Demková, K. Assessing long-term spatial changes of natural habitats using old maps and archival sources: A case study from Central Europe. Biodivers. Conserv. 2015, 24, 1899-1916. [CrossRef]

141. Cleland, E.E.; Harpole, W.S. Nitrogen enrichment and plant communities. Ann. N. Y. Acad. Sci. 2010, 1195, 46-61. [CrossRef]

142. LeBauer, D.S.; Treseder, K.K. Nitrogen limitation of net primary productivity in terrestrial ecosystems is globally distributed. Ecology 2001, 89, 371-379. [CrossRef]

143. Simkin, S.M.; Allen, E.B.; Bowman, W.D.; Clark, C.M.; Belnap, J.; Brooks, M.L. Conditional vulnerability of plant diversity to atmospheric nitrogen deposition across the United States. Proc. Natl. Acad. Sci. USA 2016, 113, 4086-4091. [CrossRef]

144. Borer, E.T.; Seabloom, E.W.; Gruner, D.S.; Harpole, W.S.; Hillebrand, H.; Lind, E.M. Herbivores and nutrients control grassland plant diversity via light limitation. Nature 2014, 508, 517. [CrossRef]

145. Hautier, Y.; Niklaus, P.A.; Hector, A. Competition for light causes plant biodiversity loss after eutrophication. Science 2009, 324, 636-638. [CrossRef]

146. Van Groeningen, J.W.; Lubbers, I.M.; Vos, H.M.J.; Brown, G.G.; De Deyn, G.B.; van Groeningen, J.K. Earthworms increase plant production: A meta-analysis. Sci. Rep. 2014, 4, 6365. [CrossRef]

147. Geiger, F.; Bengtsson, J.; Berendse, F. Persistent negative effects of pesticides and biological control potential on European farmland. Basic Appl. Ecol. 2010, 11, 97-105. [CrossRef]

148. Brittain, C.; Potts, G. The potential impacts of insecticides on the life-history traits of bees and the consequences for pollination. Basic Appl. Ecol. 2011, 12, 321-331. [CrossRef]

149. Greenwood, K.L.; McKenzie, B.M. Grazing effects on soil physical properties and consequences for pastures: A review. Aust. J. Exp. Agric. 2001, 41, 1231-1250. [CrossRef]

150. Mulholland, B.; Fullen, M.A. Cattle trampling and soil compaction on loamy sands. Soil Use Manag. 1991, 7 , 189-193. [CrossRef]

151. Kniezková, T. Interest of Czech population in water management. Eur. Countrys. 2013, 5, 197-211. [CrossRef]

152. Basso, B.; De Simone, L.; Ferrara, A.; Cammarano, D.; Cafiero, G.; Yeh, M.-L.; Chou, T.-Y. Analysis of contributing factors to desertification and mitigation measures in Basilicata Region. Ital. J. Agron. 2010, 5 , 33-44. [CrossRef]

153. Prokopová, M.; Cudlín, O.; Včeláková, R.; Lengyel, S.; Salvati, L.; Cudlín, P. Latent Drivers of Landscape Transformation in Eastern Europe: Past, Present and Future. Sustainability 2018, 10, 2918. [CrossRef]

154. Ibáñez, J.; Martínez, J.; Schnabel, S. Desertification due to overgrazing in a dynamic commercial livestock-grass-soil system. Ecol. Model. 2007, 205, 277-288. [CrossRef]

155. Di, H.J.; Cameron, K.C.; Milne, J.; Drewry, J.J.; Smith, N.P.; Hendry, T.; Moore, S.; Reijnen, B. A mechanical hoof for simulating animal treading under controlled conditions. N. Z. J. Agric. Res. 2001, 44, 111-116. [CrossRef]

156. Estel, S.; Kuemmerle, T.; Alcantara, C.; Levers, C.; Prishepov, A.; Hostert, P. Mapping farmland abandonment and recultivation across Europe using MODIS NDVI time series. Remote Sens. Environ. 2015, 163, 312-325. [CrossRef]

157. Hiernaux, P.; Bielders, C.L.; Valentin, C.; Bationo, A.; Fernandéz-Rivera, S. Effects of livestock grazing on physical and chemical properties of sandy soils in Sahelian rangelands. J. Arid Environ. 1999, 41, 231-245. [CrossRef]

158. Manzano, M.G.; Navar, J. Processes of desertification by goats overgrazing in the Tamaulipan thornscrub (matorral) in north-eastern Mexico. J. Arid Environ. 2000, 44, 1-17. [CrossRef]

159. Caraveli, H. A comparative analysis on extensification and intensification in Mediterranean agriculture: Dilemmas for LFAs policy. J. Rural Stud. 2000, 16, 231-242. [CrossRef] 
160. MacDonald, D.; Crabtree, J.R.; Wiesinger, G.; Dax, T.; Stamou, N.; Fleury, P.; Lazpita, J.G.; Gibon, A. Agricultural abandonment in mountain areas of Europe: Environmental consequences and policy response. J. Environ. Manag. 2000, 59, 47-69. [CrossRef]

161. Stoate, C.; Baldi, A.; Beja, P.; Boatman, N.D.; Herzon, I.; van Doorn, A.; de Snoo, G.R.; Rakosy, L.C.; Ramwell, C. Ecological impacts of early 21st century agricultural change in Europe-A review. J. Environ. Manag. 2009, 91, 22-46. [CrossRef]

162. Bielsa, I.; Pons, X.; Bunce, R.G.H. Agricultural abandonment in the north eastern Iberian Peninsula: The use of basic landscape metrics to support planning. J. Environ. Plan. Manag. 2005, 48, 85-102. [CrossRef]

163. Pykälä, J.; Luoto, M.; Heikkinen, R.K.; Kontula, T. Plant species richness and persistence of rare plants in abandoned semi-natural grasslands in northern Europe. Basic Appl. Ecol. 2005, 6, 25-33. [CrossRef]

164. Prach, K. Spontaneous vegetation succession in human-disturbed habitats: A pattern across seres. Appl. Veg. Sci. 2001, 4, 83-88. [CrossRef]

165. Tabeni, S.; Yannelli, F.A.; Vezzani, N.; Mastrantonio, L.E. Indicators of landscape organization and functionality in semi-arid former agricultural lands under a passive restoration management over two periods of abandonment. Ecol. Indic. 2016, 66, 488-496. [CrossRef]

166. Bolliger, J.; Kienast, F.; Soliva, R.; Rutherford, G. Spatial sensitivity of species habitat patterns to scenarios of land use change (Switzerland). Landsc. Ecol. 2007, 22, 773. [CrossRef]

167. Carvalho-Santos, C.; Honrado, J.P.; Hein, L. Hydrological services and the role of forests: Conceptualization and indicator-based analysis with an illustration at a regional scale. Ecol. Complex. 2014, 20, 69-80. [CrossRef]

168. Beilin, R.; Lindborg, R.; Stenseke, M.; Pereira, E.M.; Llausàs, A.; Slätmo, E.; Cerqueira, Y.; Navarro, L.; Rodrigues, P.; Reichelt, N.; et al. Analysing how drivers of agricultural land abandonment affect biodiversity and cultural landscapes using case studies from Scandinavia, Iberia and Oceania. Land Use Policy 2014, 36, 60-72. [CrossRef]

169. Burnside, N.G.; Joyce, C.B.; Puurmann, E.; Scott, D.M. Use of vegetation classification and plant indicators to assess grazing abandonment in Estonian coastal wetlands. J. Veg. Sci. 2007, 18, 645-654. [CrossRef]

170. Flinn, K.M.; Vellend, M. Recovery of forest plant communities in post-agricultural landscapes. Front. Ecol. Environ. 2005, 3, 243-250. [CrossRef]

171. Vassilev, K.; Pedashenko, H.; Nikolov, S.C.; Apostolova, I.; Dengler, J. Effect of land abandonment on the vegetation of upland semi-natural grasslands in the Western Balkan Mts.; Bulgaria. Plant Biosyst. 2011, 145, 654-665. [CrossRef]

172. Wiezik, M.; Svitok, M.; Wieziková, A.; Dovčiak, M. Shrub encroachment alters composition and diversity of ant communities in abandoned grasslands of western Carpathians. Biodivers. Conserv. 2013, 22, 2305-2320. [CrossRef]

173. Calsamiglia, A.; Lucas-Borja, M.E.; Fortesa, J.; Garcia-Comendador, J.; Estrany, J. Changes in Soil Quality and Hydrological Connectivity Caused by the Abandonment of Terraces in a Mediterranean Burned Catchment. Forests 2017, 8, 333. [CrossRef]

174. Ceccarelli, T.; Bajocco, S.; Perini, L.; Salvati, L. Urbanisation and Land Take of High-Quality Agricultural Soils-Exploring Long-term Land Use Changes and Land Capability in Northern Italy. Int. J. Environ. Res. 2014, 8, 181-192.

175. Van der Walt, L.; Cilliers, S.S.; Kellner, K.; Du Toit, M.J.; Tongway, D. To what extent does urbanisation affect fragmented grassland functioning? J. Environ. Manag. 2015, 151, 517-530. [CrossRef]

176. Craul, P.J. A description of urban soils and their desired characteristics. J. Arboricult. 1985, 11, 330-339.

177. McDonnell, M.J.; Pickett, S.T.A.; Groffman, P.; Bohlen, P.; Pouyat, R.V.; Zipperer, W.C.; Parmelee, R.W.; Carreiro, M.M.; Medley, K. Ecosystem processes along an urban-to-rural gradient. Urban Ecosyst. 1997, 1, 21-36. [CrossRef]

178. Geslin, B.; Gauzens, B.; Thébault, E.; Dajoz, I. Plant Pollinator Networks along a Gradient of Urbanisation. PLoS ONE 2013, 8, e63421. [CrossRef]

179. Fontaine, C.; Dajoz, I.; Meriguet, J.; Loreau, M. Functional diversity of plant- pollinator interaction webs enhances the persistence of plant communities. PLoS Biol. 2006, 4, 129-135. [CrossRef]

180. Zambon, I.; Benedetti, A.; Ferrara, C.; Salvati, L. Soil matters? A multivariate analysis of socioeconomic constraints to urban expansion in Mediterranean Europe. Ecol. Econ. 2018, 146, 173-183. [CrossRef] 
181. Zitti, M.; Ferrara, C.; Perini, L.; Carlucci, M.; Salvati, L. Long-term urban growth and land use efficiency in Southern Europe: Implications for sustainable land management. Sustainability 2015, 7, 3359-3385. [CrossRef]

182. Serra, P.; Vera, A.; Tulla, A.F.; Salvati, L. Beyond urban-rural dichotomy: Exploring socioeconomic and land-use processes of change in Spain (1991-2011). Appl. Geogr. 2014, 55, 71-81. [CrossRef]

183. Thomsen, M.; Faber, J.H.; Sorensen, P.B. Soil ecosystem health and services Evaluation of ecological indicators susceptible to chemical stressors. Ecol. Indic. 2012, 16, 67-75. [CrossRef]

184. Anandhi, A. CISTA-A: Conceptual model using indicators selected by systems thinking for adaptation strategies in a changing climate: Case study in agro-ecosystems. Ecol. Model. 2017, 345, 41-55. [CrossRef]

(C) 2019 by the authors. Licensee MDPI, Basel, Switzerland. This article is an open access article distributed under the terms and conditions of the Creative Commons Attribution (CC BY) license (http://creativecommons.org/licenses/by/4.0/). 